\title{
Effects of an elemental diet, inert bulk and different types of dietary fibre on the response of the intestinal epithelium to refeeding in the rat and relationship to plasma gastrin, enteroglucagon, and PYY concentrations
}

\author{
R A GoOdLAD, W LENTON, M A GHATEI, T E ADRIAN, S R BLOOM, \\ AND N A WRIGHT
}

From Cancer Research Campaign Cell Proliferation Unit, Department of Histopathology; and Department of Medicine, Royal Postgraduate Medical School, Hammersmith Hospital, London

SUMMARY Refeeding starved rats with an elemental diet resulted in a marked increase in crypt cell production rate (CCPR) in the proximal small intestine but not in the distal regions of the gut. Little effect on CCPR was noted when inert bulk (kaolin) was added to the elemental diet. Addition of a poorly fermentable dietary fibre (purified wood cellulose) had little effect on intestinal epithelial cell proliferation except in the distal colon where it significantly increased CCPR. A more readily fermentable fibre (purified wheat bran) caused a large proliferative response in the proximal, mid, and distal colon and in the distal small intestine. A gel forming fibre only significantly stimulated proliferation in the distal colon; the rats in this group, however, did not eat all the food given. There was no significant correlation between CCPR and plasma gastrin concentrations, but plasma enteroglucagon concentrations were significantly correlated with CCPR in almost all the sites studied. Plasma PYY concentrations also showed some correlation with CCPR, especially in the colon. Thus while inert bulk cannot stimulate colonic epithelial cell proliferation fermentable fibre is capable of stimulating proliferation in the colon, and especially in the distal colon: it can also stimulate proliferation in the distal small intestine and it is likely that plasma enteroglucagon may have a role to play in this process.

The intestinal epithelium can respond to a wide variety of stimuli by altering its proliferative rates. ${ }^{12}$ Feeding animals with low bulk chemically defined semisynthetic (elemental) diets causes atrophy and reduced intestinal cell proliferation. ${ }^{3-9}$ This has been attributed to lack of non-absorbable bulk, ${ }^{10}$ but more recent work strongly suggests that it is because of lack of dietary fibre. ${ }^{11-14}$ The term dietary fibre encompasses a wide range of diverse substances which

Address for correspondence: Dr R A Goodlad, Dept of Histopathology, Royal Postgraduate Medical School, Hammersmith Hospital, Ducane Road, London, W12 0HS.

Received for publication 30 May 1986 cannot be digested without the action of the gut microflora. ${ }^{15}$ The proliferative effects of the various types of fibre also appears to vary,$^{14}$ this may be because of the differences in the ease with which they can be fermented in the hind gut, as there is evidence that the products of hind gut fermentation can have a trophic effect on the gastrointestinal epithelium. ${ }^{16}$ Such an effect could be direct or indirect, and if the latter, a hormonal mechanism may be implicated. Two of the hormones which have most often been implicated in the control of intestinal epithelial cell proliferation are enteroglucagon and gastrin. ${ }^{17}$

One way of studying the mechanisms involved in the regulation of intestinal epithelial cell proliferation without recourse to grossly unphysiological 
stimuli is to investigate the response of the gut to starvation and refeeding. ${ }^{18} 19$

The hypothesis that hind gut fermentation stimulates colonic epithelial cell proliferation was tested in the present study by comparing the effects on the intestinal epithelium of refeeding starved rats with an elemental diet supplemented with inert bulk (kaolin), a poorly digestible fibre (wood cellulose), a digestible bran concentrate (Trifyba) and a soluble non-starch polysaccharide which forms a gel in water (prepared from the ispaghula husk). Refeeding with the elemental diet alone or with a standard rat chow was also studied.

The proliferative rates of the above treatments were also compared with the plasma hormone concentrations of gastrin, enteroglucagon, and peptide YY (PYY), a new candidate hormone ${ }^{20}$ which appears to be colocalised with enteroglucagon. ${ }^{21-23}$

\section{Methods}

\section{ANIMALS}

Male Wistar rats were used (Olac Ltd, Blackthorn, Oxon, UK). Their mean body weights are shown in Table 1 . They were kept on wire bottomed cages and fed a powdered version of a standard laboratory diet (Labshure PRD, Christopher Hill, Poole, Dorset) for two weeks before the start of the experiment and were then fed or starved as described in the experimental design below. They had constant access to water.

\section{EXPERIMENTAL DESIGN}

Eight groups of 10 rats were used. Group A was fed the powdered laboratory rodent diet PRD throughout the investigation, group B was starved for three days and then killed. Groups C, D, E, F, G, and H

Table 1 Body weight changes and per cent weight changes of the various groups of rats during the course of the investigation.

\begin{tabular}{|c|c|c|c|c|c|c|c|c|c|c|}
\hline \multirow[b]{2}{*}{ Group } & \multicolumn{2}{|c|}{$\begin{array}{l}\text { Start } \\
\text { weight } \\
\text { (g) }\end{array}$} & \multicolumn{2}{|c|}{$\begin{array}{l}\text { Weight } \\
\text { after } \\
3 \text { days } \\
\text { starvation }\end{array}$} & \multicolumn{2}{|c|}{$\begin{array}{l}\text { Weight } \\
\text { decrease } \\
(g)(\%)\end{array}$} & \multicolumn{2}{|c|}{$\begin{array}{l}\text { Weight } \\
\text { at end } \\
\text { of } \\
\text { experiment }\end{array}$} & \multicolumn{2}{|c|}{$\begin{array}{l}\text { Weight } \\
\text { increase } \\
\text { upon re- } \\
\text { feeding }(\%)\end{array}$} \\
\hline & Mean & $S E$ & Mean & $S E$ & Mean & $S E$ & Mean & $S E$ & Mean & $S E$ \\
\hline $\bar{A}$ & $236 \cdot 6$ & $2 \cdot 8$ & & & & & 252.2 & 2.9 & & \\
\hline B & $237 \cdot 8$ & $3 \cdot 0$ & $192 \cdot 0$ & $3 \cdot 1$ & $18 \cdot 7$ & 0.5 & & & & \\
\hline C & 236.7 & 3.8 & 186.7 & 3.7 & $21 \cdot 1$ & 0.9 & 194.4 & $2 \cdot 6$ & $4 \cdot 3$ & $1 \cdot 2$ \\
\hline , & $235 \cdot 0$ & $2 \cdot 4$ & 184.0 & $2 \cdot 1$ & $21 \cdot 7$ & $0 \cdot 6$ & $183 \cdot 5$ & $2 \cdot 6$ & -0.3 & 0.5 \\
\hline $\mathrm{E}$ & $238 \cdot 0$ & $2 \cdot 3$ & 189.5 & 1.6 & $20 \cdot 4$ & 0.6 & 198.5 & $2 \cdot 1$ & $4 \cdot 8$ & 1.0 \\
\hline $\mathbf{F}$ & $227 \cdot 0$ & $2 \cdot 8$ & $181 \cdot 5$ & $2 \cdot 1$ & $20 \cdot 0$ & 0.8 & 187.0 & $3 \cdot 2$ & $3 \cdot 1$ & $1 \cdot 5$ \\
\hline G & $242 \cdot 0$ & $4 \cdot 5$ & $194 \cdot 1$ & 4.0 & $19 \cdot 6$ & $2 \cdot 1$ & $198 \cdot 0$ & $3 \cdot 6$ & $2 \cdot 1$ & $0 \cdot 5$ \\
\hline $\mathrm{H}$ & $239 \cdot 5$ & 2.9 & 193.5 & $2 \cdot 4$ & $19 \cdot 2$ & 0.5 & 213.0 & $2 \cdot 4$ & $10 \cdot 1$ & $0.6^{*}$ \\
\hline
\end{tabular}

*Significantly greater than all the other refed groups $\mathrm{p}<0.001$ were starved for three days and then refed for two days. All refed groups were given $15 \mathrm{~g} / \mathrm{rat} /$ day of their respective diets at 0900 hours. Group $\mathrm{G}$ was refed the PRD diet and group $\mathrm{H}$ was refed with the elemental diet Flexical (Mead Johnson, Slough). The diet for group $\mathrm{C}$ was a 1:1 mixture of Flexical and kaolin. Diet D was a 1:1 mixture of Flexical and cellulose (Solka Floc grade BW-100, Johnsen Jorgensen and Wettre Ltd, London). Diet E was a 1:1 mixture of Flexical and a fibrous extract of wheat grain Trifyba (Labaz Sanofi UK Ltd, Wythenshawe, Manchester; hemicellulose $40 \%$, cellulose $20 \%$, lignin $15 \%$ and pectin $5 \%$ ). Diet $\mathrm{F}$ was a $1: 1$ mixture of Flexical and the dietary mucilage prepared from the ispaghula husk ${ }^{24}$ (Reckitt \& Colman, Hull).

The rats were weighed at the beginning of the experiment, after starvation and after refeeding. They were injected with vincristine at the end of the experiment so that the crypt cell production rate (CCPR) could be determined.

\section{PROXIMATE ANALYSES OF THE DIETS $(\mathrm{g} / \mathrm{kg})$ Labshure PRD}

Barley, oats, wheat, wheatfeed, maize meal, soya bean extract, dried skim milk, dried yeast, white fish meal minerals and vitamins (crude protein 201, crude oil 28, crude fibre 52 energy content $9341 \mathrm{~kJ}$ (2254 kcal)).

\section{Flexical}

Sucrose, maize syrup solids, enzymically hydrolised casein, tapioca starch, soya bean oil, medium chain triglycerides (fractionated coconut oil) citric acid, mono- and diglycerides, lecithin, amino acids (Lmethionine, L-tyrosine L-trypophan) vitamins and minerals (protein equivalent 99, fat 150 , carbohydrate 678, ash 27, moisture 15 energy content 17782 kJ (4250 kcal)).

\section{Crypt cell production rate (CCPR)}

The use of valid methods for the quantification of proliferation is vitally important and a rate measure such as the crypt cell production rate (CCPR) method is one of the few methods which is robust enough to withstand criticism. ${ }^{25}{ }^{26}$ The rats were given an intraperitoneal injection of vincristine sulphate (Tillots laboratories, Henlow Bedfordshire UK) at 0900 hours and were killed at timed intervals 30 to 180 minutes later. Samples of the small intestine and colon (as defined by their position in the small intestine and colon relative to length) were removed and fixed in Carnoy's fluid. The tissue was later stained with the Feulgen reaction and the intestinal or colonic crypts were displayed by microdissection (Fig. 1); the number of arrested metaphases in 10 crypts was then counted and the mean values plotted 


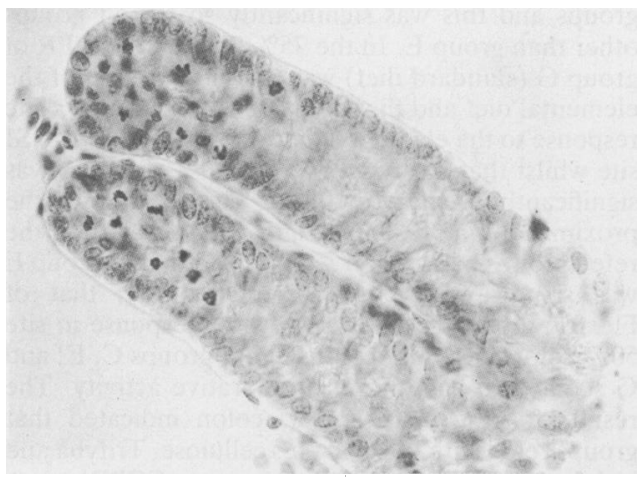

Fig. 1 Microdissected small intestinal crypt squash preparation. The tissue was stained with the Feulgen reaction and then gently teased apart to display intact crypts. Note the dense hyperchromatic vincristine arrested metaphase nuclei.

against time after injection. The slope of the line, fitted by least squares linear regression, gave the CCPR. ${ }^{26}$

\section{HORMONE ASSAYS}

Gut hormones were measured using previously described radioimmunoassays for gastrin ${ }^{27}$ pancreatic glucagon $^{28}$ enteroglucagon $^{29}$ and PYY. ${ }^{30}$ Enteroglucagon was calculated by subtracting specifically measured pancreatic glucagon (C-terminal immunoreactivity measured with antiserum RCS5 from total N-terminal glucagon immunoreactivity (measured with antiserum R59)). The assays were capable of detecting the following plasma changes with $95 \%$ confidence gastrin $2 \mathrm{pmol} / \mathrm{l}$, pancreatic glucagon $2 \mathrm{pmol} / 1$, enteroglucagon $5 \mathrm{pmol} / 1$, and PYY 2.5 $\mathrm{pmol} / \mathrm{l}$.

\section{STATISTICAL ANALYSIS}

Crypt cell production rate and weights are shown \pm standard errors. Differences between groups were tested by a two-sided Student's $t$ test. Crypt cell production rates were compared by a computer based $t$ test using a pooled estimate of standard error. Correlations between CCPR's and hormone levels were tested by the Pearson product moment correlation method and Spearmans rank correlation method.

\section{Results}

All groups, except those fed diet F (Flexical plus ispaghula) ate all their food ( $15 \mathrm{~g} / \mathrm{rat} / \mathrm{day})$. The rats in group $\mathrm{F}$ consumed only $8 \mathrm{~g} / \mathrm{rat} / \mathrm{day}$. The intestines of this group was found on necropsy to be distended with the gel like ispaghula, suggesting that the physical distension of the gut had inhibited food intake.

After one days refeeding groups $\mathrm{C}$ (Flexical + kaolin) and D (Flexical + wood cellulose) produced a considerable amount of white faeces, group $E$ (Flexical + Trifyba) produced large dark faeces, group $F$ (Flexical + ispaghula) only produced a few pale gelatinous faeces. The faeces of the rats fed the standard diet $(G)$ were normal in colour and quantity whilst those fed Flexical on its own $(\mathrm{H})$ had very few faeces and some of the rats in this group showed signs of diarrhoea.

The body weights of the various groups at different phases of the investigation are shown in Table 1. Analysis of variance showed that there were no significant differences in the start weights, weights after starvation and the percent weight losses. The mean weight loss for all the groups after three days starvation was $20 \cdot 1 \% \pm 0 \cdot 4 \%$. All groups except group D (Flexical + wood cellulose) showed a modest increase in body weight upon refeeding and the weight increase of group $\mathrm{H}$ (Flexical) was significantly $(p<0.001)$ greater than that of the other groups. There was no significant interaction between groups for the other refed groups.

\section{CRYPT CELL PRODUCTION RATES}

The crypt cell production rates (CCPR's) of the sites studied in the small intestine are shown in Figures 2-4 and the CCPR's of the colonic sites are in Figures 5-7. Starvation significantly decreased CCPR in all sites $(p<0.001)$ except for the mid colon where $\mathrm{p}<0 \cdot 05$.

Refeeding the rats led to a general increase in CCPR but this was only significant for group $\mathbf{H}$ (Flexical diet) in the $25 \%$ SI and $75 \%$ SI sites, for group $\mathrm{G}$ (Standard diet) in the $75 \%$ SI site and for group $\mathrm{E}$ (Flexical + Trifyba) in all sites except $25 \%$ SI; thus diet $\mathrm{E}$ had by far the most pronounced proliferative effect.

The CCPR of the refed groups were still significantly lower than that of the fed group for all groups in the small intestine except group $\mathrm{E}$ in the $75 \% \mathrm{SI}$ site. The CCPR in the colon was still less than that of the fed group (A) except for those of groups $E$ (refed Flexical + Trifyba) and $G$ (refed standard diet) for the $10 \%$ colon site, most groups except $E$ in the $50 \%$ colon site and all the groups except D, E, and F in the $90 \%$ colon site. See Table 2 . The CCPR of group $E$ (refed Flexical + Trifyba) in the distal colon was significantly greater than that of the fed group (A) $(\mathrm{p}<0 \cdot 01)$.

The CCPR's of the various groups expressed as a percentage of the values in group $\mathbf{H}$ (Flexical alone) are shown in Table 3 . The CCPR of group $\mathrm{H}$ in the $25 \%$ SI site was greater than that of all the other refed 


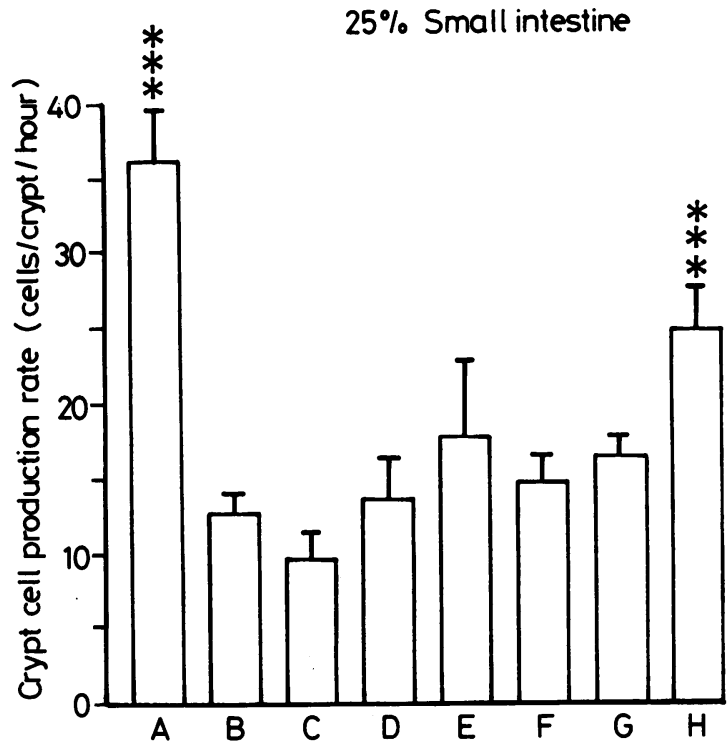

Fig. 2 Crypt cell production rates in the proximal small intestine $(25 \%$ of the distance from pylorus to ileocaecal valve). Group $A=$ Fed group (powdered laboratory rat diet). Group $B=$ Starved for 3 days. Group $C=$ Starved then refedFlexical + kaolin. Group D=Starved then refed-Flexical + wood cellulose. Group E=Starved then refed-Flexical + Trifyba. Group $F=$ Starved then refed-Flexical + ispaghula mucilage. Group $G=$ Starved then refed-Powdered standard diet. Group $H=$ Starved then refed-Flexical.

* = significantly different than group $B p<0.05$

** = significantly different than group $B p<0.01$

*** = significantly different than group $B p<0.001$

Table 2 Crypt cell production rate of the various groups expressed as a percentage of the values obtained in group $A$ (fed rats) and the $p$ values for these when tested against group A. For errors see Figs. 1-6

\begin{tabular}{|c|c|c|c|c|c|c|}
\hline & \multicolumn{2}{|l|}{$25 \% S I$} & \multicolumn{2}{|l|}{$75 \% S I$} & \multicolumn{2}{|l|}{$90 \% S I$} \\
\hline & \multicolumn{2}{|c|}{$C C P R p<$} & \multicolumn{2}{|c|}{$C C P R p<$} & \multicolumn{2}{|c|}{$C C P R p<$} \\
\hline Group B & 34.8 & & $18 \cdot 7$ & 0.001 & $19 \cdot 1$ & 0.001 \\
\hline C & $27 \cdot 1$ & 0.001 & $32 \cdot 9$ & 0.001 & 24.9 & 0.001 \\
\hline D & $38 \cdot 2$ & 0.001 & $17 \cdot 9$ & 0.001 & $17 \cdot 8$ & 0.001 \\
\hline $\mathrm{E}$ & $49 \cdot 6$ & 0.001 & $83 \cdot 7$ & & $73 \cdot 3$ & 0.05 \\
\hline $\mathbf{F}$ & $41 \cdot 2$ & 0.001 & 42.9 & 0.001 & 31.0 & 0.001 \\
\hline \multirow{4}{*}{$\mathbf{H}$} & $46 \cdot 2$ & 0.01 & $57 \cdot 3$ & 0.01 & $37 \cdot 0$ & 0.001 \\
\hline & 69.9 & 0.01 & $52 \cdot 3$ & 0.01 & $33 \cdot 8$ & 0.001 \\
\hline & \multicolumn{2}{|c|}{$10 \%$ colon } & \multicolumn{2}{|c|}{$50 \%$ colon } & \multicolumn{2}{|c|}{$90 \%$ colon } \\
\hline & $C C P R$ & $p<$ & $C C P R$ & $p<$ & $C C P R$ & $p<$ \\
\hline B & 0.6 & 0.001 & $21 \cdot 5$ & & 2.9 & 0.001 \\
\hline C & $13 \cdot 2$ & 0.001 & $79 \cdot 7$ & 0.01 & $36 \cdot 5$ & \\
\hline D & 13.4 & 0.001 & $34 \cdot 2$ & & $82 \cdot 5$ & \\
\hline $\mathbf{E}$ & $64 \cdot 2$ & & $96 \cdot 2$ & & 189.4 & 0.01 \\
\hline $\bar{F}$ & $25 \cdot 8$ & 0.01 & $11 \cdot 4$ & 0.01 & $96 \cdot 1$ & \\
\hline $\mathbf{G}$ & $52 \cdot 2$ & & $72 \cdot 2$ & & $40 \cdot 4$ & \\
\hline $\mathbf{H}$ & $7 \cdot 1$ & 0.001 & $35 \cdot 4$ & & $38 \cdot 5$ & \\
\hline
\end{tabular}

groups and this was significantly so for all groups other than group E. In the $75 \%$ SI site the CCPR of group $\mathrm{G}$ (standard diet) was the same as that of the elemental diet and that of group $\mathrm{E}$ was greater. The response to the elemental diet was less in the $90 \%$ SI site whilst that of group E (Flexical + Trifyba) was significantly greater $(\mathrm{p}<0.01)$. The CCPR's of the proximal colon ( $10 \%$ of length) showed that all the refed groups had greater CCPRs and that of group $\mathrm{E}$ was significantly $(p<0.05)$ greater than that of Flexical alone $(\mathrm{H})$. The pattern of response in site $50 \%$ colon was more confused but groups $\mathrm{C}, \mathrm{E}$, and $\mathrm{G}$ seemed to have more proliferative activity. The results for the distal $(90 \%)$ colon indicated that groups refed with Flexical plus cellulose, Trifyba and isphagula $(D, E$, and $F)$ had greater CCPR's than those fed Flexical alone $(\mathrm{H})$ and the CCPR of group $E$ was significantly $(p<0 \cdot 001)$ greater.

PLASMA HORMONE CONCENTRATIONS

The effect of the various treatments on plasma enteroglucagon, gastrin and PYY are shown in

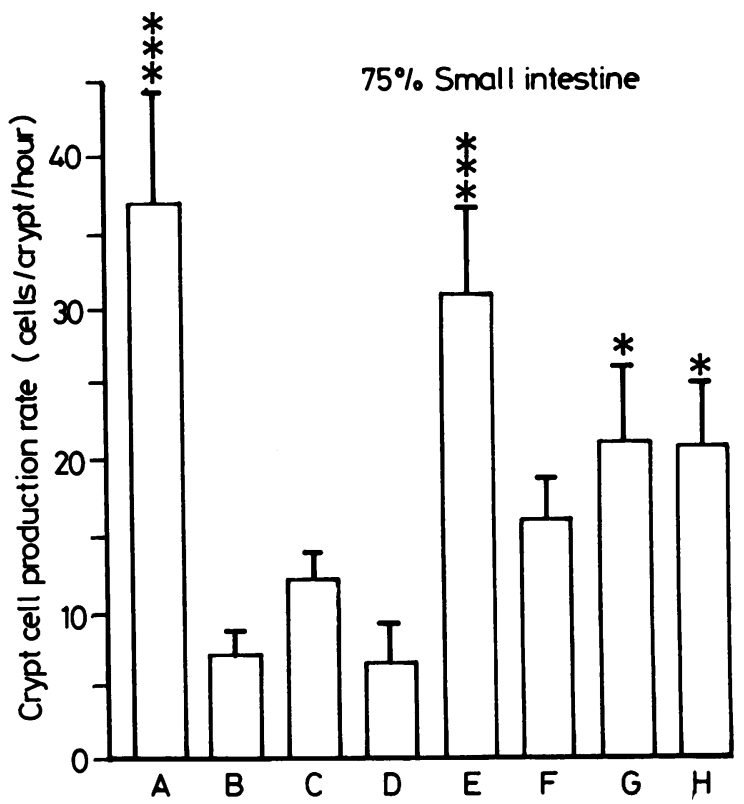

Fig. 3 Crypt cell production rates in the mid ileum (75\% of the distance from pylorus to ileocaecal valve). Group $A=$ Fed group (powdered laboratory rat diet). Group $B=$ Starved for 3 days. Group $C=$ Starved then refed - Flexical + kaolin. Group $D=$ Starved then refed - Flexical + wood cellulose. Group $E=$ Starved then refed - Flexical + Trifyba. Group $F=$ Starved then refed-Flexical + ispaghula mucilage. Group $G=$ Starved then refed-Powdered standard diet. Group $H=$ Starved then refed-Flexical.

* = significantly different than group $B$ p $<0.05$

** = significantly different than group $B p<0.01$

*** = significantly different than group $B$ p $<0.001$ 
Figures 8,9 , and 10 . Starvation significantly lowered the plasma concentrations of all hormones $(p<0.001)$. Plasma enteroglucagon increased significantly after refeeding in all groups except group C (Flexical + kaolin) (where $p<0.055$ ) see Figure 8. Analysis of variance showed that plasma gastrin concentrations were not significantly altered after refeeding. There were, however, significant differences (by analysis of variance) between the enteroglucagon concentra-

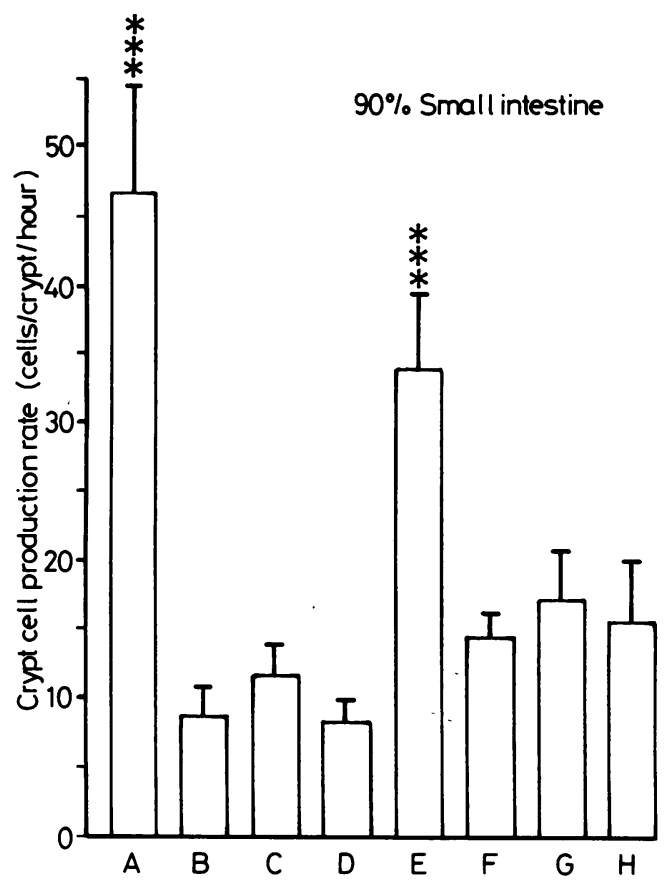

Fig 4 tions of the refed groups $(p<0.01)$ the highest levels being in groups $\mathrm{E}$ (Flexical + Trifyba) and $\mathrm{H}$ (Flexical alone) respectively. Plasma concentrations of PYY also showed significant $(p<0.001$ by analysis of variance) differences between the refed groups, mainly due to there being a marked increase in PYY levels in groups refed with Flexical + Trifyba or isphagula ( $E$ and $F)$.

Pearsons product moment correlation showed

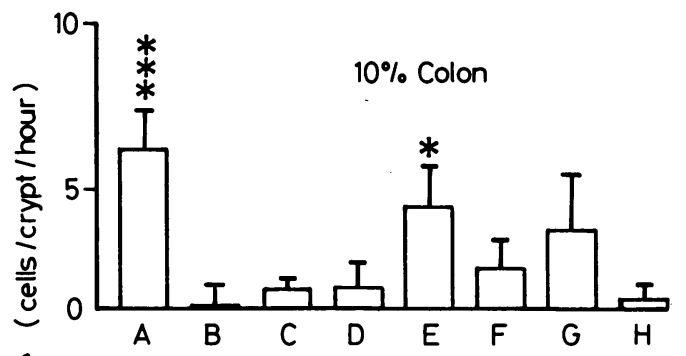

Fig 5

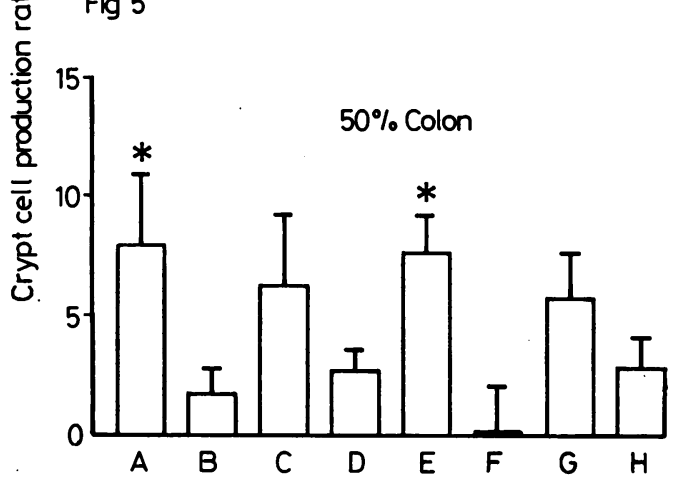

Fig 6

Fig. 4 Crypt cell production rates in the terminal ileum ( $90 \%$ of the distance from pylorus to ileocaecal valve). Group A=Fed

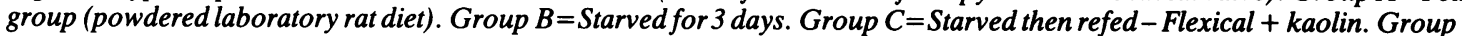
$D=$ Starved then refed-Flexical + wood cellulose. Group $E=$ Starved then refed-Flexical + Trifyba. Group $F=S t a r v e d$ then refed-Flexical + ispaghula mucilage. Group $G=$ Starved then refed-Powdered standard diet. Group $H=S t a r v e d$ then refed - Flexical.

${ }^{*}=$ significantly different than group $B p<0.05^{* *}=$ significantly different than group $B p<0.01$

$* * *=$ significantly different than group $B p<0 \cdot 001$

Fig. 5 Crypt cell production rates in the proximal colon (10\% of the distance from caecum to rectum). Group A=Fed group (powdered laboratory rat diet). Group $B=$ Starved for 3 days. Group $C=$ Starved then refed - Flexical + kaolin. Group $D=$ Starved then refed - Flexical + wood cellulose. Group $E=$ Starved then refed - Flexical + Trifyba. Group $F=$ Starved then refed-Flexical + ispaghula mucilage. Group $G=$ Starved then refed - Powdered standard diet. Group $H=$ Starved then refed - Flexical.

${ }^{*}=$ significantly different than group $B p<0.05^{* *}=$ significantly different than group $B p<0.01$

$* * *=$ significantly different than group $B p<0.001$

Fig. 6 Crypt cell production rates in the mid colon ( $50 \%$ of the distance from caecum to rectum). Group A=Fed group (powdered laboratory rat diet). Group B =Starved for 3 days. Group C =Starved then refed - Flexical + kaolin. Group $D=$ Starved then refed - Flexical + wood cellulose. Group $E=$ Starved then refed - Flexical + Trifyba. Group $F=$ Starved then refed-Flexical + ispaghula mucilage. Group $G=$ Starved then refed-Powdered standard diet. Group $H=$ Starved then refed - Flexical.

${ }^{*}=$ significantly different than group $B p<0.05^{* *}=$ significantly different than group $B p<0.01$

$* * *=$ significantly different than group $B p<0.001$ 
Table 3 Crypt cell production rate of the various groups expressed as a percentage of the values obtained in group $H$ (fed the elemental diet Flexical). For standard errors see Figs. $1-6$.

\begin{tabular}{|c|c|c|c|c|c|}
\hline & \multicolumn{2}{|l|}{$25 \% S I$} & $75 \% S I$ & \multicolumn{2}{|l|}{$90 \% S I$} \\
\hline & $C C P R$ & $p<$ & $C C P R p<$ & $C C P R$ & $p<$ \\
\hline Group A & $143 \cdot 0$ & 0.01 & $\begin{array}{ll}177 \cdot 8 & 0.01\end{array}$ & $296 \cdot 2$ & 0.001 \\
\hline B & $49 \cdot 8$ & 0.01 & $\begin{array}{ll}33.3 & 0.05\end{array}$ & $56 \cdot 7$ & \\
\hline $\mathrm{C}$ & $38 \cdot 6$ & $0 \cdot 001$ & $58 \cdot 5$ & 73.9 & \\
\hline D & $54 \cdot 6$ & 0.01 & 31.9 & $52 \cdot 9$ & \\
\hline $\mathrm{E}$ & $70 \cdot 9$ & & $148 \cdot 8$ & $217 \cdot 2$ & 0.01 \\
\hline $\mathrm{F}$ & $59 \cdot 0$ & 0.02 & $76 \cdot 3$ & 91.7 & \\
\hline \multirow[t]{3}{*}{ G } & $66 \cdot 1$ & 0.05 & $101 \cdot 9$ & $109 \cdot 5$ & \\
\hline & \multicolumn{2}{|c|}{$10 \%$ colon } & $50 \%$ colon & \multicolumn{2}{|c|}{$90 \%$ colon } \\
\hline & $C C P R$ & $p<$ & $C C P R p<$ & $C C P R$ & $p<$ \\
\hline A & 1413.0 & 0.01 & $282 \cdot 1$ & $260 \cdot 0$ & \\
\hline B & 8.7 & & $60 \cdot 7$ & $7 \cdot 5$ & \\
\hline $\mathrm{C}$ & $187 \cdot 0$ & & $225 \cdot 0$ & $95 \cdot 0$ & \\
\hline D & 189.1 & & $96 \cdot 4$ & $215 \cdot 0$ & \\
\hline $\mathrm{E}$ & 906.5 & 0.05 & 271.4 & 492.5 & 0.001 \\
\hline $\mathrm{F}$ & $365 \cdot 2$ & & $3 \cdot 2$ & $250 \cdot 0$ & \\
\hline G & $737 \cdot 0$ & & $203 \cdot 6$ & $105 \cdot 0$ & \\
\hline
\end{tabular}

Table 4 Spearmans rank correlation coefficient for crypt cell production rates and plasma hormone levels

\begin{tabular}{llll}
\hline & $\begin{array}{l}\text { Plasma } \\
\text { enteroglucagon }\end{array}$ & $\begin{array}{l}\text { Plasma } \\
\text { gastrin }\end{array}$ & $\begin{array}{l}\text { Plasma } \\
P Y Y\end{array}$ \\
\hline 25\% small intestine & $0 \cdot 881 \dagger$ & -0.095 & $0 \cdot 667^{*}$ \\
$75 \%$ small intestine & $0.738^{*}$ & $-0 \cdot 024$ & $0 \cdot 571$ \\
$90 \%$ small intestine & $0 \cdot 738^{*}$ & $-0 \cdot 024$ & $0 \cdot 571$ \\
$10 \%$ colon & $0.690^{*}$ & $0 \cdot 381$ & $0 \cdot 643^{*}$ \\
$50 \%$ colon & $0 \cdot 500$ & $0 \cdot 452$ & $0 \cdot 310$ \\
$90 \%$ colon & $0.833 \dagger$ & $0 \cdot 333$ & $0 \cdot 810^{*}$ \\
\hline
\end{tabular}

${ }^{*} \mathrm{p}<0.05 ; \mathrm{tp}<0.01$

significant correlations between CCPR and plasma enteroglucagon in four sites $(\mathrm{p}<0.001)$ to $\mathrm{p}<0.02)$ and between CCPR and plasma PYY in four sites $(p<0.01)$ and between CCPR and gastrin in three sites $(p<0.05)$; however, these correlations were unduly influenced by the high CCPRs and hormone concentrations in group A (fed) as Figures 11 and 12 show. Spearmans rank correlation was thus used to reduce this bias, see Figures 13 and 14 . The results for the Spearmans correlation are shown in Table 4. Plasma enteroglucagon concentrations were significantly correlated with the CCPRs of all sites except the mid colon. Plasma PYY concentrations were significantly correlated with the CCPR in three sites, two of these being in the colon. There was no significant correlation between plasma gastrin concentrations and CCPR or between plasma gastrin level and enteroglucagon or PYY (rs $=0 \cdot 190,0.286$ ) Plasma PYY was, however, significantly correlated with enteroglucagon $(\mathrm{rs}=0.905, \mathrm{p}<0.01)$.

\section{Discussion}

The results of the present study show that a low residue elemental diet is capable of stimulating an adaptive response after refeeding, as was observed after intestinal resection ${ }^{31}$ and that the effects of such diets are mainly confined to the proximal regions of the gastrointestinal tract. ${ }^{78}$ These effects may also vary with the type of elemental diet ${ }^{32}$ and Flexical can maintain small bowel mass more than some other elemental diets. ${ }^{33}$ Elemental diets require minimal digestion and are mainly absorbed in the proximal regions of the small intestine, thus the trophic responses reported here are compatible with the effects of luminal nutrition or mucosal workload. ${ }^{17}$

It is worth noting that the CCPR's of the fed group (A) were considerably greater than the control values from other experiments done in this laboratory such as ${ }^{18}$ which suggests that giving a standard diet in powdered form also stimulates proliferation, perhaps because of it being readily digested or to changes in intestinal transit time.

The diminished proliferative response seen in the distal gut of group $\mathrm{H}$ (refed with Flexical), which occurred despite the considerably greater calorific value of this diet confirms that such diets deprive the distal gut of luminal nutrition and/or functional demand. The greater calorific value of this diet was reflected in the significantly greater weight gain of group $\mathbf{H}$.

Reduced rates of hind gut epithelial proliferation have been linked with lack of bulk. ${ }^{1034}$ An increase

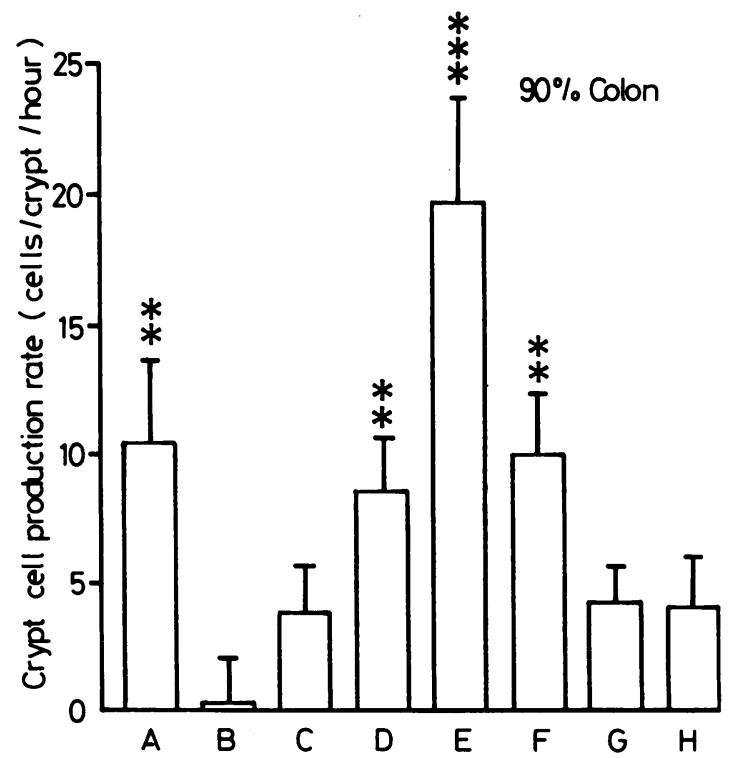

Fig. 7 Crypt cell production rates in the distal colon $(90 \%$ of the distance from caecum to rectum). 


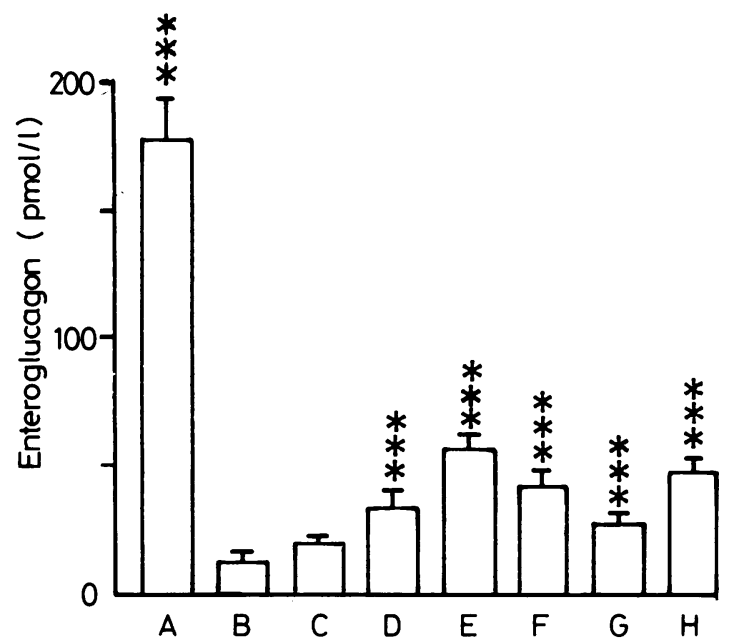

Fig. 8 Plasma enteroglucagon concentrations. Group $A=$ Fed group (powdered laboratory rat diet). Group $B=$ Starved for 3 days. Group $C=$ Starved then refed Flexical + kaolin. Group $D=$ Starved then refed-Flexical + wood cellulose. Group E =Starved then refed - Flexical + Trifyba. Group $F=$ Starved then refed-Flexical + ispaghula mucilage. Group $G=$ Starved then refed-Powdered standard diet. Group $H=S t a r v e d$ then refed-Flexical.

${ }^{*}=$ significantly different than group $B p<0.05$

** = significantly different than group $B p<0 \cdot 01$

$* * *=$ significantly different than group $B p<0.001$

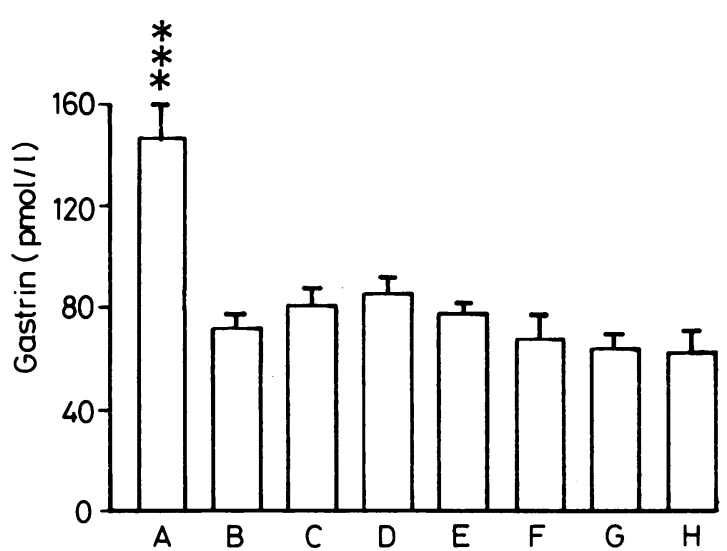

Fig. 9 Plasmagastrin levels. Group $A=$ Fed group (powdered laboratory rat diet). Group $B=$ Starved for 3 days. Group C=Starved then refed-Flexical + kaolin. Group $D=$ Starved then refed - Flexical + wood cellulose. Group $E=$ Starved then refed - Flexical + Trifyba. Group $F=$ Starved then refed-Flexical + ispaghula mucilage. Group $G=$ Starved then refed - Powdered standard diet. Group $H=$ Starved then refed-Flexical.

* = significantly different than group $B p<0.05$

${ }^{* *}=$ significantly different than group $B p<0.01$

$* * *=$ significantly different than group $B$ p $<0.001$ in colonic weight has been reported after feeding inert bulk (kaolin) ${ }^{35}$ however, colonic weight also includes the muscle layer, and we have previously shown ${ }^{7}$ that kaolin can increase colonic muscle weight without affecting the mucosa. Bulky wheat bran can increase the size of colonic muscle cells whilst oat bran and pectin supplemented diets decrease the size of muscle cells. ${ }^{36}$ The CCPR's obtained for group C (Flexical + kaolin) confirm that inert bulk has little effect on mucosal proliferation.

The CCPR's obtained on refeeding diet C (Flexical + kaolin) confirm that bulk (kaolin) has little effect on mucosal proliferation. ${ }^{7}$ All the groups except group F (Flexical + ispaghula) ate all the food given. The intestine of group $F$ were distended with the swollen gel from stomach to colon and it is probable that this inhibited food intake. The amounts of fibre given in this study were far greater than those expected in normal diets, but such levels have been tolerated by rats in other studies. ${ }^{37}$ Despite the reduced food intake of group $\mathrm{F}$ a significant effect on CCPR was noted in the distal colon and there was some indication of a proliferative effect in the small intestine $75 \%$ site.

Diet D (Flexical + wood cellulose) also had a significant effect on the CCPR of the distal colon despite the poor digestibility of this fibre compared with the more natural bran like fibres. ${ }^{15}$ Addition of

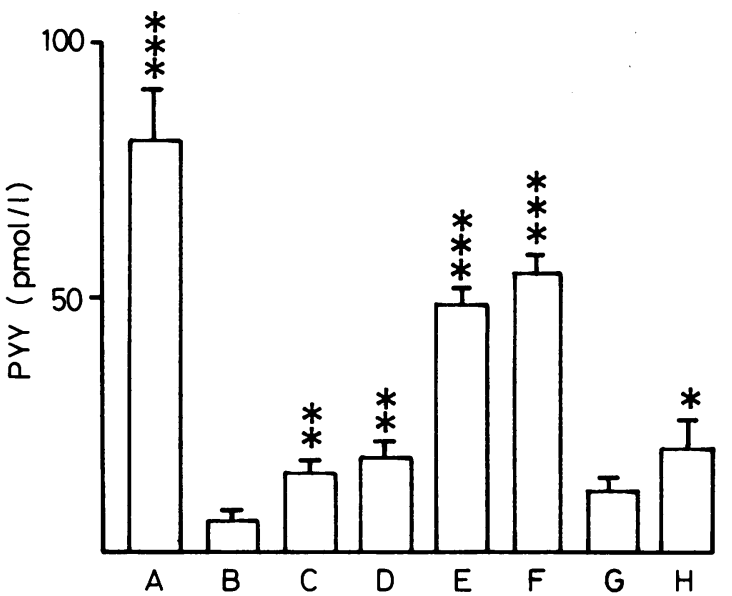

Fig. 10 Plasma Peptide YY (PYY) levels. Group A=Fed group (powdered laboratory rat diet). Group $B=S$ Starved for 3 days. Group $C=$ Starved then refed - Flexical + kaolin. Group $D=$ Starved then refed-Flexical + wood cellulose. Group E $=$ Starved then refed-Flexical + Trifyba. Group $F=$ Starved then refed-Flexical + ispaghula mucilage. Group $G=$ Starved then refed-Powdered standard diet. Group $H=$ Starved then refed-Flexical.

${ }^{*}=$ significantly different than group $B p<0.05$

${ }^{* *}=$ significantly different than group $B p<0.01$

$* * *=$ significantly different than group $B p<0.001$ 

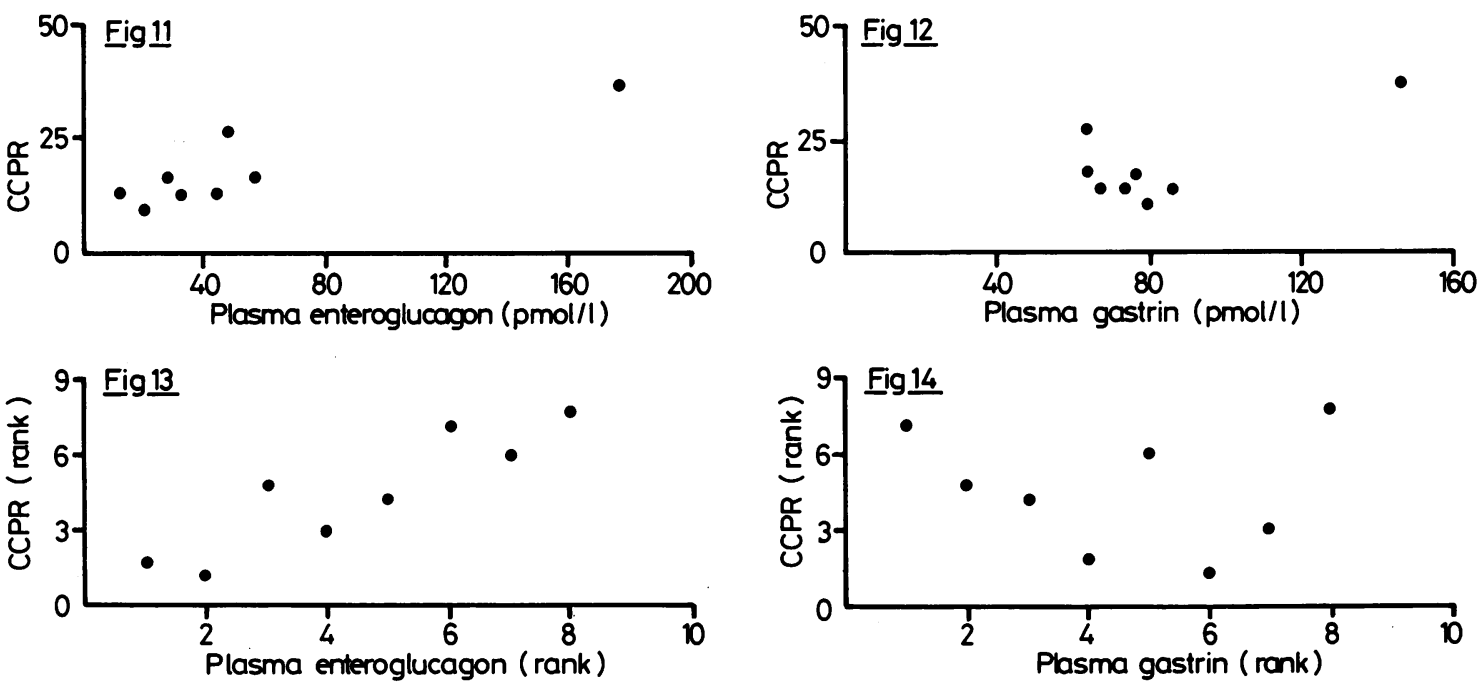

Fig. 11 Plot of plasma enteroglucagon concentrations versus crypt cell production rates for the proximal small intestine ( $25 \%$ of the distance from pylorus to ileocaecal valve).

Fig. 12 Plot of plasma gastrin levels versus crypt cell production rates for the proximal small intestine (25\% of the distance from pylorus to ileo-caecal valve).

Fig. 13 Rank plot of plasma enteroglucagon concentrations versus crypt cell production rates for the proximal small intestine ( $25 \%$ of the distance from pylorus to ileocaecal valve).

Fig. 14 Rank plot of plasma gastrin concentrations versus crypt cell production rates for the proximal small intestine (25\% of the distance from pylorus to ileocaecal valve).

the purified wheat bran fibre Trifyba (diet E) had a dramatic stimulatory effect on the CCPR of almost all sites. This was most pronounced in the distal colon. The response of the colon to fibre in other experiments ${ }^{12}$ also suggests that the distal colon is more susceptible than the proximal colon to such stimuli. It is interesting to note that most experimentally induced colonic tumours occur in the mid to distal zones of the large bowel. ${ }^{38}{ }^{39}$ Colonic epithelial hyperplasia has been associated with increases in carcinogenesis which is consistent with the two step model of carcinogenesis where proliferation can promote a previously initiated cell.$^{39}$ Enhancement of colon carcinogenesis in the rat has been reported after supplementation with wheat bran, ${ }^{40}$ this was especially so when given at the same time as the carcinogen which was also the regime that caused the maximum increase in hyperplasia ${ }^{41}$ however, when the bran diet was given after the carcinogen there were less tumours. ${ }^{40}$ The maximum yield of tumours was, however, obtained when a fibre free diet was given after the carcinogen; fibre free diets have been associated with reduced levels of enzymes which can detoxify certain xenobiotic chemicals. ${ }^{42}$

Dietary fibre has several effects on the bowel, all of which may affect carcinogenesis. Fibre can delay gastric emptying and impede or delay absorption, alter transit times, dilute or bind carcinogens, alter bile acid levels and cholesterol levels and induce xenobiotic metabolising enzymes. ${ }^{4243}$ Hind gut fermentation plays an important role in the energy balance of most single stomached mammals including man, ${ }^{44}$ and the products of this fermentation are the short chain fatty acids (SCFA's) or volatile fatty acids (VFA's). The release of these SCFA's also has several effects on the colon such as lowering the luminal $\mathrm{pH}$, increasing mucosal blood flow, altering ammonia concentrations and increasing water absorption. . $5-17^{-17}$

The main SCFA's are acetic acid, proprionic acid and butyric acid. Butyric acid is preferentially metabolised by isolated colonocytes. ${ }^{45}$ SCFA's have been reported to have a trophic effect in the large and small intestine ${ }^{164950}$ and the response to the different fibres suggests that the more readily fermentable fibres had the greatest effect. It is thus likely that rodent hind gut mucosal cell proliferation can also be stimulated by SCFAs as is the forestomach of ruminants where inert sponges had no effect on epithelial development but SCFAs stimulated proliferation. ${ }^{1151}$ A considerable proportion of SCFA's are metabolised by the epithelial cells of the colon or by the 
liver. ${ }^{375253}$ Trophic effects could be caused by either the SCFAs or by their metabolites or by some other systemic factor.

Plasma enteroglucagon concentrations have previously been linked with increased $C C P R^{17}$ and the correlation between the plasma concentrations of this hormone and the CCPR in this investigation suggest that enteroglucagon may be involved in moderating this effect. Enteroglucagon cells are present throughout the gut but most are localised in the terminal ileum and colon ${ }^{54}$ which is a strategic position for monitoring SCFA release (or the presence of undigested food). Peptide YY distribution in the gut is similar to that of enteroglucagon ${ }^{21-23}$ and it is interesting that most of the correlation between PYY and CCPR was due to the high levels of PYY in groups $E$ and $F$ which had the most readily fermented diets and that two of three of the PYY correlations observed occured in the colon. Peptide YY can inhibit gastric acid secretion and stomach emptying $^{556}$ thus active fermentation in the colon may be a signal for delaying gastric digestion and emptying mediated via PYY. A role for PYY in the control of gastrointestinal epithelial cell proliferation is less certain as although PYY levels have been shown to correlate with CCPR in resected rats, direct infusion of PYY has little effect on CCPR. ${ }^{57}$

The conclusions of the present study are thus; that while a fibre free diet can stimulate epithelial cell proliferation in the proximal small intestine of refed rats, cell proliferation in the distal gut and colon requires other factors. The hypothesis that inert bulk is required is not bourne out. Readily fermentable fibre can be effective in stimulating proliferation, the release of SCFAs into the lumen could account for the proliferative effects noted. These proliferative effects were also noted in the small intestine and plasma enteroglucagon was implicated in this.

We are pleased to acknowledge the financial assistance of the Cancer Research Campaign. We thank Reckitt \& Colman for the ispaghula gel, Labaz Sanofi UK Ltd for the Trifyba and Johnsen Jorgensen \& Wettre for the Solka Floc.

\section{References}

1 Diamond JM, Karasowov WH. Trophic control of the intestinal mucosa. Nature (Lond) 1983; 304: 18.

2 Wright NA, Alison M. Growth and proliferative responses of the gastrointestinal tract. In: The biology of epithelial cell populations. Vol 2. Oxford: Clarendon Press, 1984: 743-76.

3 Janne P, Carpenter Y, Willems G. Colonic mucosal atrophy induced by a liquid elemental diet in rats. $\mathrm{Am} \mathrm{J}$ Dig Dis 1977; 22: 808-12.
4 Storme G, Willems $\mathrm{G}$. The effects of a liquid elemental diet on cell proliferation in the colon of rats. Cell Tissue Res 1981; 216: 221-5.

5 Lehnert S. Changes in growth kinetics of jejunal epithelium in mice maintained on an elemental diet. Cell Tissue Kinet 1979; 12: 239-48.

6 Nelson LM, Carmichael HA, Russel RI, Lee FD. Small intestinal changes induced by an elemental diet in normal rats. Clin Sci Mol Med 1978; 55: 509-11.

7 Goodlad RA, Wright NA. Effects of addition of kaolin or cellulose to an elemental diet on intestinal cell proliferation in the mouse. Br J Nutr 1983; 50: 91-8.

8 Morin CL, Ling V, Bourassa D. Small intestinal and colonic changes induced by a chemically defined diet. Dig Dis Sci 1980; 25: 123-8.

9 Sircar B, Johnson LR, Lichtenberger LM. Effects of synthetic diets on gastrointestinal mucosal DNA synthesis in rats. Am J Physiol 1983; 244: G327-G35.

10 Ryan GP, Dudrick SJ, Copeland EM, Johnson LR. Effect of various diets on colonic growth in rats. Gastroenterology 1979; 77: 658-63.

11 Sakata T, Hikosaka K, Shiomura Y, Tamate H. Stimulatory effects of butyrate on epithelial cell proliferation in the rumen of the sheep and its mediation by insulin. Differences between in vivo and in vitro studies. In: Appleton DR, Sunter JP, Watson AC, eds. Cell proliferation in the gastrointestinal tract. Bath: Pitman Press, 1980: 123-37.

12 Jacobs LR, Schneeman BO. Effects of dietary wheat bran on rat colonic structure and mucosal cell growth. J Nutr 1981; 111: 798-803.

13 Tasmanjones C, Owen RL, Jones AL. Semipurified dietary fibre and small bowel morphometry in rats. Dig Dis Sci 1982; 27: 519-24.

14 Jacobs LR, Lupton JR. Effects of dietary fibres on rat large bowel mucosal growth and cell proliferation. Am J Physiol 1984; 246: G378-G85.

15 Van Soest PJ. Some physical characteristics of dietary fibre and their influences on microbial ecology of the human colon. Proc Nutr Soc 1984; 43: 25-33.

16 Sakata T, Yajima T. Influence of short chain fatty acids on the epithelial cell division of digestive tract. $Q J$ exp Physiol 1984; 69: 639-48.

17 Wright NA, Alison M. The control of cell proliferation in the gastrointestinal tract. In: The biology of epithelial cell populations. Vol 2. Oxford: Clarendon Press, 1984: 842-67.

18 Goodlad RA, Al-Mukhtar MYT, Ghatei MA, Bloom SR, Wright NA. Cell proliferation, plasma enteroglucagon and plasma gastrin levels in starved and refed rats. Virch Arch [Cell Pathol] 1983; 43: 55-62.

19 Goodlad RA, Wright NA. The effects of starvation and refeeding on intestinal cell proliferation in the mouse. Virchows Arch [Cell Pathol] 1984; 45: 63-73.

20 Tatemoto K, Mutt V. Isolation of two novel candidate hormones using a chemical method for finding naturally occurring polypeptides. Nature 1980; 285: 417-8.

21 El-Salhy M, Wilander E, Juntti-Berggren L, Grimelius L. The distribution and ontogeny of polypeptide YY (PYY) and pancreatic polypeptide (PP)-immunoreactive cells in the gastrointestinal tract of rat. Histochemistry 1983; 78: 53-60. 
22 Ali-Rachedi, Varndell IM, Adrian TE, et al. Peptide YY (PYY) immunoreactivity is co-stored with glucagonrelated immunoreactants in endocrine cells of the gut and pancreas. Histochemistry 1984; 80: 487-91.

23 El-Salhy M, Grimelius L, Wilander E, et al. Immunocytochemical identification of polypeptide YY (PYY) cells in the human gastrointestinal tract. Histochemistry 1983; 77:15-23.

24 Sandhu JS, Hudson GJ. The gel nature and structure of the carbohydrate of Ispaghula husk ex Plantago ovato Forsk. Carbohydrate Res 1981; 93: 247-59.

25 Al-Mucktar MYT, Polak JM, Bloom SR, Wright NA. The search for appropriate measurements of proliferative and morphological status in studies on intestinal adaptation. In: Robinson JWL, Dowling RH, Reicken JWL, eds. Intestinal adaptation II. Lancaster: MTP Press Ltd, 1982: 3-25.

26 Goodlad RA, Wright NA. Quantitative studies on epithelial replacement in the gut. In: Titchen TA, ed. Techniques in the life sciences. Techniques in digestive physiology. Vol P2. Dublin: Elsevier Biomedical Press. 1982: 212/1-212/23.

27 Russel RCG, Bloom SR, Fielding LP, Bryant MG. Current problems in the measurement of gastrin release. Postgrad Med J 1976; 52: 645-50.

28 Alford FP, Bloom SR, Nabarro JDN. Glucagon levels in normal and diabetic subjects. Use of specific immunoabsorbent for glucagon radioimmunoassay. Diabetologia 1977; 13: 1-6.

29 Ghatei MA, Bloom SR. Enteroglucagon in man. In: Bloom SR, Polak JM, eds. Gut hormones. Edinburgh: Churchill Livingstone, 1981: 332-8.

30 Adrian TE, Ferri G-L, Bacarese-Hamilton AJ, Fuessl HS, Polak JM, Bloom SR. Human distribution of a putative new gut hormone, Peptide YY. Gastroenterology 1985; 89: 1070-7.

31 Fenyo $G$, Halberg $D$. The influence of a chemical diet on the intestinal mucosa after jejuno-ileal bypass in the rat. Acta Chir Scand 1976; 142: 270-4.

32 Nelson LM, Russel RI, Lee FD. Elemental diet composition and the structure and function of rat small intestine: Comparison of the effects of two diets on morphology and in vivo absorption of water. J Parent Ent Nutr 1981; 5: 204-6.

33 Young EA, Cioletti LA, Traylor JB, Balderas V. Gastrointestinal response to nutrient variation of defined formula diets. J Parent Ent Nutr 1981; 5: 478-84.

34 Bristol JB, Williamson RCN. Large bowel growth. Scand J Gastroenterol 1984; 19: 25-34.

35 Dowling RH, Reicken EO, Laws JW, Booth CC. The intestinal response to high bulk feeding in the rat. Clin Sci 1967; 32: 1-9.

36 Jacobs LR. Differenteral effects of dietary fibers on rat intestinal circular muscle cell size. Dig Dis Sci 1985; 30: 247-52.

37 Demigne C, Remesy C. Stimulation of absorption of volatile fatty acids and minerals in the ceacum of rats adapted to a very high fibre diet. $J$ Nutr $1985 ; 115$ :53-60.

38 Williamson RCN, Rainey JB. The relationship between intestinal hyperplasia and carcinogenesis. Scand $J$ Gastroenterol 1984; 19: 57-76.

39 Wright NA, Alison M. Cell proliferation in gastrointes- tinal carcinogenesis. In: The biology of epithelial cell populations. Vol 2. Oxford: Claredon Press, 1984: 805-39.

40 Jacobs LR. Enhancement of rat colon carcinogenesis by wheat bran consumption during the stage of 1,2-dimethylhydrazine administration. Cancer Res 1983; 43: 4057-61.

41 Jacobs LR. Stimulation of rat colonic crypt cell proliferative activity by bran consumption during the stage of 1,2-dimethylhydrazine administration. Cancer Res 1984 ; 44: 2458-63.

42 Hoensch HP, Steinhardt HJ, Weiss G, Haug D, Maier A, Malchow H. Effects of semisynthetic diets on xenobiotic metabolizing enzyme activity and morphology of small intestinal mucosa in humans. Gastroenterology 1984; 86: 1519-30.

43 Cummings JH, Branch WJ. Postulated mechanisms whereby fibre may protect against large bowel cancer. In: Vahouny GV, Kritchevsky P, eds. Dietary fibre in health and disease. New York: Plenum, 1982: 313-26.

$44 \mathrm{McNeil}$ NI. The contribution of the large intestine to energy supplies in man. Am J Clin Nutr 1984; 39: 338-42.

45 Cummings JH. Cellulose and the human gut. Gut 1984; 24: 805-10.

46 Kvietys PR, Granger DN. Effect of volatile fatty acids on blood flow and oxygen uptake by the dog colon. Gastroenterology 1981; 80: 962-9.

47 Cummings JH. Short chain fatty acids in the human colon. Gut 1981; 22: 763-79.

48 Roediger WEW. Utilization of nutrients by isolated epithelial cells of the rat colon. Gastroenterology 1982; 83: 424-9.

49 Sakata T. Short chain fatty acids as the luminal trophic factor. Can J Anim Sci 1984; 64: 189-90.

50 Tutton PJM, Barkla DH. Further studies on the effect of adenosine cyclic monophosphate derivatives on cell proliferation in the jejunal crypts of rat. Clin Exp Pharm Physiol 1982; 9: 671-4.

51 Flatt WP, Warner RG, Loosli JK. Influence of purified materials on the development of the ruminant stomach. J Dairy Sci 1958; 41: 1593-600.

52 Vernay M, Marty J. Absorption and metabolism of butyric acid in rabbit hind gut. Comp Biochem Physiol 1984; 77: 89-96.

53 Marty JF, Vernay MY, Abravanel GM. Acetate absorption and metabolism in the rabbit hindgut. Gut 1985; 26: 2-569.

54 Bloom SR. Gut and brain - endocrine connections. $J R$ Coll Physicians (Lond) 1980; 14: 51-7.

55 Sukuki T, Nakaya M, Itoh Z, Tatemoto K, Mutt V. Inhibition of interdigestive contractile activity in the stomach by peptide YY in Heidenhain pouch dogs. Gastroenterology 1983; 85: 114-21.

56 Allen JM, Fitzpatrick ML, Yeats JC, Darcy K, Adrian TE, Bloom SR. Effects of peptide YY and neuropeptide $\mathrm{Y}$ on gastric emptying in man. Digestion 1984; 30: $255-62$.

57 Savage A, Gornacz GE, Adrian TE, Goodlad RA, Wright NA, Bloom SR. Elevation of PYY following intestinal resection in the rat is not responsible for the adaptive response. Gut 1985; 26: 1353-8. 